Revista de Estudios Histórico-Jurídicos

[Sección historia del derecho europeo]

XLI (Valparaíso, Chile, 2019)

[pp. 207 - 234]

\title{
DELIBERACIONES DEL LEGISLADOR DECIMONÓNICO EN TORNO AL DELITO DE ARMAS PROHIBIDAS
}

\author{
[Deliberations of the nineteenth century legislator on the offense of possessing \\ prohibited weapons] \\ Julián Gómez de MayA* \\ Universidad de Murcia, España
}

\section{RESUMEN}

El delito de armas prohibidas, rigurosamente castigado en las recopilaciones de la Edad Moderna, se ve sometido a la hora de la codificación penal a reconsideración bajo un paradigma, el del humanitarismo ilustrado, que siempre encubre o entraña además cálculos de eficacia represiva tendentes a fiar antes el logro de los fines políticocriminales en la indefectibilidad de unas penas proporcionadas que en su aspereza o magnitud. A lo largo del siglo XIX el legislador va a debatirse entre el mantenimiento de la categoría delictiva, por supuesto que con penalidad ya minorada, su degradación a rango de falta o su conversión en circunstancia agravante de la responsabilidad criminal, hasta que la siguiente centuria-al impulso doctrinal del defensismo o del fenómeno de administrativización del derecho penal hacia su hipertrofia-recupere definitivamente el delito de tenencia ilícita de armas, bien dentro de los sucesivos códigos, bien como legislación de carácter especial.

\section{Palabras Clave}

Codificación - Código Penal tipicidad delictiva - armas prohibidas - humanización penal.

\section{Abstract}

The unlawful possession of prohibited weapons, rigorously punished in the collections of Modern Age, is, in the codification of criminal law, reviewed under the paradigm of an illustrated humanitarianism, which always disguises or also entails estimates of efficacy of repression, attempting to guarantee, in the first place, the achievement of political-criminal aims in the indefectibility of some proportional sanctions instead of guaranteeing harsher or lengthy punishments. During the 19th century, the legislator sits between keeping the criminal category (with reduced penalty, of course), its downgrading to misdemeanor or turning it into aggravating circumstance of criminal liability, until the following century -by the doctrinal drive of utmost defense or utmost administrative paperwork of the criminal law leading it to hypertrophypermanently reestablishes the unlawful possession of prohibited weapons fully within the subsequent criminal codes, specifically the legislation.

KeYwORDS
Codification - Criminal Code - cri-
minal designation - prohibited weapons
- humanization of crime.

RECIBIDO el 5 de octubre de 2018 y ACEPTADO el 30 de abril de 2019

* Profesor de Historia del Derecho y de las Instituciones, Universidad de Murcia, Facultad de Derecho, Departamento de Historia Jurídica, Campus de la Merced, C/ Santo Cristo, 1. CP 30001, Murcia. gomezdemaya@um.es 
A decir de Joaquín Francisco Pacheco, el más célebre y eficaz comentarista del genesíaco impulso codificador que cubre, en lo criminal, la primera mitad del siglo XIX español, "[...] en ninguna materia precisamente ha habido tanta confusión, en ninguna ha habido tanto desorden, como en ésta de las armas que tratamos": primero, por falta de fijeza y certidumbre en su tipicidad, con un estatuto escaso, o scuro, contradictorio, absurdo alguna vez; segundo, por inobservancia de toda igualdad en la práctica, y tanto -¡la típica hipérbole de Pacheco!- "[...] que no habrá habido quizás un juez, de cuantos han aplicado las leyes de armas prohibidas, que no fuesen ellos propios reos del mismo delito que penaban" "... Pero todavía a esa inseguridad jurídica y a esa inequidad ha de sumarse otra tacha: la de un rigorismo descomedido, reservando el jurista y político ecijano para este sector y factor criminógeno uno de sus no menos característicos juicios execratorios del derecho que la codificación pretendía dejar atrás: "nuestra legislación recopilada, y más todavía nuestras costumbres judiciales, eran de un rigor excesivo respectivamente al uso de ciertas armas. En ese uso, en su posesión siquiera, habian constituido un delito especial, que castigaban muy severamente. Tener una pistola o una navaja de cierto tamaño, ha sido con frecuencia bastante causa para sufrir una condena de cuatro o seis años de presidio" ${ }^{2}$. El ministro -moderado- de los códigos de 1848 y 1850, Lorenzo Arrazola, ratifica el anacronismo, la severidad extrema, la desproporción y el desuso casi completo, ante lo cual "los tribunales, siguiendo la marcha de la opinion, dictaban penas discrecionales" ${ }^{3}$, siendo estas - nos informa otro ministro de Gracia y Justicia, el de 1842, José Alonso- variables por consiguiente: “[...] en unos se ha tomado el medio de disminuir la pena reduciendo los seis años á uno, dos, ó algunos meses, y en otros se convierte esta pena en pecuniaria"; mas esto no con total elusión de riesgos, pues "[...] reconocido así por los tribunales, á pesar de esto se han procesado algunos ministros por no haber aplicado la pena durísima que hay establecida, y es indispensable que se trate de cortar este conflicto" "4 que llevaba a los magistrados de una audiencia a comparecer ante el Tribunal Supremo, por mucho que la causa formada se cerrase después con su sobreseimiento... Y el principalísimo exégeta del siguiente hito codificador, el de 1870, Alejandro Groizard, subrayará por igual en cuánta medida "importantes son las variaciones que ha sufrido esta materia en el transcurso de algunos años. Nuestras antiguas leyes castigaban la simple aprehension de armas prohibidas, blancas ó de fuego con seis años de presidio ó de galera segun que fueran nobles ó plebeyos aquellos á quienes se ocuparan", desde donde ha concluido por llegarse a su destipificación delictiva completa, en juego un expediente u otro, desde mediada la centuria.

'PaCheCo' Joaquín Francisco, El Código Penal concordado y comentado (1848, reimpr., Madrid, Edisofer, 2000), p. 258.

${ }^{2}$ Pacheco, Joaquín Francisco, cit. (n.1), p. 258.

${ }^{3}$ Arrazola, Lorenzo, et al., Enciclopedia española de derecho y administracion ó Nuevo teatro universal de la legislacion (Madrid, Andrés y Díaz, 1850), III, pp. 590, 592.

${ }_{4}^{4}$ Diario de las sesiones de Cortes. Congreso de los Diputados. Legislatura de 1841 á 1842, II, ses. 87 (12-IV-1842), pp. 2373-2374.

${ }^{5}$ Groizard y Gómez de la Serna, Alejandro, El Código Penal de 1870 concordado y comentado (Burgos/Salamanca, Timoteo Arnáiz/Esteban Hermanos, 1870/1899), I, pp. 365-366. 
Había venido a recalar en esta el segmento criminológico de las armas prohibidas embaulado en la Nueva Recopilación de las leyes destos reinos, de donde pasó muy en breve, con las reiteraciones intermedias, al título XIX del libro XII de la Novísima Recopilación de las Leyes de España ${ }^{6}$, destacable entre todo el acervo la más reciente pragmática-sanción de armas prohibidas del 26 de abril del año 1761. Ahora bien, acerca de estos instrumentos de los crímenes así de temederos para un ordenamiento que ya sabemos judicialmente enmendado por discreto humanitarismo, se lamentaba Joaquín Escriche a la altura de 1838 de que "[...] por desgracia no se observa la ley prohibitiva con la exactitud que seria de desear", habiendo como "[...] hay pueblos en que se fabrican á ciencia y paciencia de todo el mundo, y en que los vendedores salen á ofrecerlos á todo pasagero" Luego pondrá Pacheco el acento, junto a la desmesura de la reacción estatal, en el fracaso de su municionamiento pragmática tras pragmática, porque las armas objeto de tales leyes "[...] estaban prohibidas; $y$, sin embargo, se construian y vendian públicamente"; en efecto, estos artículos "[...] han estado expuestos de venta en cuantos establecimientos se han querido dedicar a este tráfico" ${ }^{8}$, evidencia esta que en correlativas palabras de Florencio García Goyena pasa por lo mas chocante é injustificable del asunto9. Ya, con este delito en el visor, el marqués de Beccaria se había pronunciado en 1764 para diagnosticar errores de política legislativa que por el decurso de un vivir cotidiano atravesado de plurifactoriedad paraban en abonada inaplicación de las normas en aquellos incursas: "[...] falsa idea de utilidad es aquella que antepone los inconvenientes particulares al inconveniente general [...]. Falsa idea de utilidad es aquella que sacrifica mil ventajas reales por un inconveniente imaginario o de poca consecuencia [...], que sólo destruyendo repara los males. De esa naturaleza son las leyes que prohiben llevar armas; no contienen más que a los no inclinados ni determinados a cometer delitos, pero los que tienen atrevimiento para violar las más sagradas de la humanidad y las más importantes del códice, ¡cómo respetarán las menores y las más puramente arbitrarias, cuyas contravenciones deben ser tanto más fáciles e impunes cuanto su ejecución exacta quita la libertad personal, tan amada del hombre y tan amada del legislador, sometiendo los inocentes a todas las vejaciones que debieran sufrir los reos? Empeoran éstas la condición de los asaltados, mejorando la de los asaltadores, no minoran los homicidios sino los aumentan, porque es mayor la confianza en asaltar los desarmados que los prevenidos. Llámanse no leyes preventivas sino medrosas de los delitos; nacen de la tumultuaria impresión

${ }^{6}$ Nueva recopilacion de las Leyes destos Reynos, VI, 6 y VIII, 23; Novísima recopilación de las leyes de España, XII, 19, con realce de su ley 19. Complétese en GARCÍA GoYENA, Florencio, Código Criminal español segun las leyes y práctica vigentes comentado y comparado con el Penal de 1822, el francés y el inglés (Madrid, Viuda de Calleja é Hijos, 1843), I, pp. 234-241; y PINO ABAD, Miguel, La represión de la tenencia y uso de armas prohibidas en Castilla previa a la codificación penal, en Cuadernos de Historia del Derecho, 20 (2013), pp. 353-384.

${ }^{7}$ EsCRICHe, Joaquín, Diccionario razonado de legislacion y jurisprudencia (Madrid, Colegio Nacional de Sordo-mudos y Ciegos, 1838/1845), I, p. 348.

${ }^{8}$ Pacheco, Joaquín Francisco, cit. (n.1), p. 258.

${ }^{9}$ García Goyena, Florencio, cit. (n. 6), I, p. 241. 
de algunos hechos particulares, no de la meditación considerada de inconvenientes y provechos de un decreto universal' 10 .

No solo es esa idea de utilidad puesta por el jurisconsulto milanés en relación con las leyes que prohíben llevar armas, sino que veremos cómo sus meditaciones sobre la proporcionalidad y certidumbre de las penas también atañen de pleno a la interdicción de dichas herramientas de o para el crimen. Lo útil diverge según el sujeto y su perspectiva, tanto que, mudado el siglo, apercibirá Bentham, discernidor de utilidades como nadie, dentro "De los medios directos de prevenir los delitos", ciertos poderes que "[...] son propios únicamente de los magistrados", uno de tales el del "embargo de armas ó de otros instrumentos destinados á servir para cometer el delito que se teme ó recela”, como mecanismo profiláctico o especie de medida de seguridad, pero exorbitante a la noción de delito ${ }^{11}$. Sí admite en ella, por el contrario, Filangieri la infracción perteneciente a las armas, con repercusivo alcance para España, al menos de lege ferenda y aun quizá de lege data si nos transportamos hasta el Trienio constitucional: el Plan de Código Criminal elevado a Carlos III en 1787 por la Junta de Legislación precave, entre los delitos contra la tranquilidad y la seguridad pública, el de "traer armas prohibidas"; el título -hace notar Casabó- "coincide plenamente con el homónimo de Filangieri"12, quien, en efecto, había enunciado a su vez la conducta como "inspirar espanto y terror trayendo consigo armas probibidas por las leyes", con expreso desacuerdo "diga lo que quiera el autor del tratado de los delitos y de las penas"13.

\section{EL DELITO DE 1822}

El Código Penal de 1822 trae un capítulo "De la fabricacion, venta, introduccion y uso de armas prohibidas" perteneciente al título "De los delitos contra la seguridad interior del Estado y contra la tranquilidad y orden público", y lo configura, a imagen del código francés ${ }^{14}$, como norma penal en blanco, lo cual despierta el recelo de algunos informantes e incluso, ya en la Cámara, el diputado Vicente Sancho, que acabará adscrito al progresismo en época isabelina, vuelve a transitar el tema de la integración con los reglamentos en orden a conferir sentido a la ley criminal ${ }^{15}$. Se previene de primeras que "el que fabricare, introdujere, vendiere ó de cualquier

${ }^{10}$ Beccaria, Cesare de, De los delitos y de las penas (1764, trad. cast., Madrid, Alianza Editorial, 1968), pp. 103-104.

${ }^{11}$ Bentham, Jeremías, Tratados de legislación civil y penal (1821/1822, trad. cast., Madrid, Editora Nacional, 1981), pp. 252-254.

${ }^{12}$ Compruébese en CASABÓ RuIZ, José Ramón, Los orígenes de la codificación penal en España: el plan de Código Criminal de 1787, en Anuario de Derecho Penaly Ciencias Penales, (1969), p. 335.

${ }^{13}$ Filangieri, Cayetano, Ciencia de la legislacion, (1780, trad. cast., Madrid, Fermín Villalpando, 1821/1822), IV, p. 221.

${ }^{14}$ Código Penal francés, traducido al castellano por orden de S. M. el emperador Maximiliano I (1810, trad. cast., México, A. Boix, 1866), pp. 67-68 (art. 314). Por igual, García Goyena, Florencio, cit. (n. 6), I, pp. 241-242; o PACHECO, Joaquín Francisco, cit. (n.1), p. 260.

${ }^{15}$ Diario de las Sesiones de Cortes. Legislatura Extraordinaria. 1821 á 1822, III, no 117, ses. 20-I-1822, pp. 1917-1919. 
modo suministrare en España alguna de las armas generalmente prohibidas por los reglamentos especiales de la materia, perderá todas las que se le aprehendieren de esta clase para los efectos espresados en el artículo [...]" relativo al comiso de las armas, instrumentos ó utensilios de ejecución delictiva, viniendo obligado, además, a pagar multa equivalente al valor de las mismas y a sufrir pena de arresto de ocho días a cuatro meses ${ }^{16}$; no falta entre los informantes quien se pronuncie en favor de despenalizar dichas fabricación y venta, con ceñimiento del reproche penal al uso sin licencia ${ }^{17}$. A propósito de este y en paralelo al suministro, "el que contra alguna persona hiciere uso de cualquiera de las armas sobredichas, ó la amenazare con ellas, ó las descubriere en público, perderá tambien para el propio efecto las que le fueren aprehendidas, y sufrirá un arresto [...]" que se queda en la mitad, de cuatro días a dos meses ${ }^{18}$, ya lejos de los años de presidio deplorados por $\mathrm{Pa}$ checo. Las protestas de quienes quisieran ver perseguido no solo el uso y alarde, sino también el simple porte, se alzan tanto fuera como dentro de la Cortes ${ }^{19}$ : por ejemplo, Juan Muñoz Alanís reputa su evitación in dispensable, mediante un poco de rigor en registrar y una pena moderada inferior al mes de encierro: "[...] la comision [...] despues de proponer penas contra la fabricacion y expendicion, que es en su concepto el primer delito, prescinde del que lleva las armas ocultas y sin hacer uso de ellas, y solo trata de que se castigue al que lo hace sin justa razon, ó al que, despreciando la ley, las manifiesta, ó al que se le aprehenden cuando es arrestado por otra causa; con lo cual queda libre de pesquisas el ciudadano pacífico./ [...] No queda, pues, excluido sino el hombre pacífico que lleva el arma oculta sin hacer daño, que no causa escándalo manifestándola en público, que no hace uso de ella sino en la necesidad de defenderse, y que no da lugar tampoco á que se sospeche de su conducta cometiendo otro delito por el cual merezca ser arrestado ó detenido; y los hombres de esta clase, repito, creo yo que, ó conviene más que lleven armas, ó que no debemos pesquisar si las llevan" ${ }^{20}$.

Por eso es que, a modo de justificación específica, de estas disposiciones "esceptúanse [...] los que no hicieren uso de las armas prohibidas sino en alguno de los casos que eximen de toda pena al homicidio [...]"21 y que exoneran, por ende, al sujeto del baldón o etiquetaje delincuencial. Más allá de la delineación de acciones típicas, no menos aflora el descontento por parvedad de las penas con que se pretende sustituir la legislación histórica: entre otras instituciones, desde el Tribunal Supremo hasta las Audiencias de Madrid, Valencia o Extremadura -según lo extracta José María Calatrava, ponente ante la asamblea y principal artífice del proyecto en el seno de la comisión redactora-, "[...] la Universidad de Granada extraña la suavidad de las penas cuando las actuales han sido insuficientes; y cree que todo el que lleve, fabrique ó introduzca armas prohibidas, debe ser condenado al dia siguiente de la

${ }^{16}$ Ley del Código Penal, de 8 de junio de 1822, en Coleccion de los Decretos y Órdenes Generales Expedidos por las Cortes, 9, decr. 56, pp. 211-381, art. 358, con su remisión al art. 90.

${ }^{17}$ Diario de Cortes, III, no 117 , ses. 20-I-1822, p. 1918.

${ }^{18}$ Código de 1822 , art. 359.

${ }^{19}$ Diario de Cortes, III, no 117 , ses. 20-I-1822, pp. 1918-1919.

${ }^{20}$ Diario de Cortes, III, no 117 , ses. 20-I-1822, p. 1918.

${ }^{21}$ Código de 1822, art. 362. 
aprehension en dos á seis años de obras públicas por primera vez, é imponérsele la pena de muerte en caso de reincidencia. ;Pena de muerte por la reincidencia en el mero uso de armas prohibidas, y pena tan grave impuesta en el término de veinticuatro horas precisamente! Justamente la razón que da la Universidad de Granada para impugnar el artículo es una de las que ha tenido la comision para proponer esa pena que parece tan suave. El rigor de las señaladas hasta ahora ha sido insuficiente, es verdad; pero esta insuficiencia ha consistido principalmente, en concepto de la comision, en el rigor mismo de las penas. Hubiéranse impuesto á los que usasen armas prohibidas penas más suaves, más proporcionadas, penas que sin dificultad se hubiesen podido hacer efectivas, y entonces lo hubieran sido, y probablemente este delito se hubiera contenido mucho más. Pero la comision ha tenido otra consideracion, no solo para proponer estas penas suaves, sino para adoptar en su aplicacion otro sistema, y es que duda mucho, y yo por mi parte dudo más, de si conviene imponer pena por punto general contra el uso de armas prohibidas, porque esta es una de aquellas leyes que solo obligan, por decirlo asi, al hombre de bien, que es el que no abusa de esas armas. El picaro se cree siempre dispensado de observar esta ley, y el picaro lleva armas prohibidas, mientras que el hombre de bien, por respetar la prohibicion, se entrega indefenso en sus manos. [...] Las penas muy rigorosas en estos casos no servirán, como no han servido hasta ahora, sino para que se eluda su aplicacion ó se apliquen al que menos lo merezca, y para que los malos tengan una ventaja segura sobre los buenos. Por lo tanto, cree la comision que si el Código penal puede poner algun remedio en esta parte, el mejor es señalar penas moderadas, penas que por lo mismo faciliten su ejecucion y sean indefectibles; $y$ con esto lograremos sin duda mejores efectos que con el rigor" 22 .

La interpretación auténtica resulta completa y hasta tan expresiva que incluso en la meditación del legislador despuntan ya, de presente y a despecho de su decisión actual, las razones que le conducirán, en 1848, hasta la destipificación. Mas, no obstante ese diseño ahora o todavía contrapuesto, el delito se combina ya con la entrada de la solución vencedora un cuarto de siglo después, en cuya virtud, "todo delito en que de cualquier modo se hiciere uso de alguna arma prohibida, tendrá por esto contra si una circunstancia agravante, sin perjuicio de aplicarse al reo las penas prescritas en el articulo anterior" ${ }^{33}$; y asimismo "toda persona á quien, siendo presa, arrestada ó detenida por cualquiera otra causa, se le aprehendiere alguna arma prohibida, tendrá tambien por esto contra sí una circunstancia agravante del delito ó culpa que hubiere ocasionado su prision, arresto ó detencion, sin perjuicio de sufrir las penas prescritas [...]" en concepto del delito recién reseñado de uso, amenaza o descubrimiento ${ }^{24}$, lo cual opera en redundancia de la agravación genérica por comisión con armas -así, indiscriminadamente, sin adjetivación alguna- prevista en el título preliminar, la novedosa parte general"25, al tratar "Del modo de graduar los delitos, y aplicar y dividir las penas" y aprobada sin observaciones de

${ }^{22}$ Diario de Cortes, III, no 117, ses. 20-I-1822, p. 1917.

${ }^{23}$ Código de 1822 , art. 360.

${ }^{24}$ Código de 1822 , art. 361.

${ }^{25}$ Masferrer Domingo, Aniceto, Tradición y reformismo en la codificación penal española: hacia el ocaso de un mito. Materiales, apuntes y reflexiones para un nuevo enfoque metodológico e historiográfico del movimiento penal europeo (Jaén, Universidad de Jaén, 2003), pp. 114-117. 
informantes ni reparos por parte de los parlamentarios ${ }^{26}$ : literalmente, que "en todo delito ó culpa para la gradacion espresada [...] se tendrán por circunstancias agravantes, ademas de las que esprese la ley en los casos respectivos, las siguientes: [...] el cometerle con armas [...]"27. En suma y a tenor de la fórmula cuantificativa, algo laxa aún, puesta a contribución, el efecto -conforme esclarece Calatrava desde la tribuna- "[...] se reduce á que sirva de gobierno á los jueces de hecho para la calificacion del grado del delito" 28 , con una dinámica valorativa que se fía al arbitrio y no se deja por el momento, como a partir de 1848, a expensas del criterio de legalidad ${ }^{29}$.

De los tres autores cuya consulta reconoce explícitamente la comisión redactora $^{30}$, lo atendido de Bentham va a quedar lejano; la generalidad de Filangieri, perfectamente compatible con el código, no ilumina, sin embargo, mucho desde un punto de vista genealógico; sí tal vez, en parte como mínimo, las ingenierías de Bexon, quien había registrado ora dentro des contraventions et des fautes, ora dentro des délits contre la sureté générale et la paix publique, tanto défenses de fabriquer ou commercer certains armes como défenses de porter des armes ${ }^{31}$, con añadidura de agravante específica de portación exclusivamente para supuestos des crimes contre les choses ${ }^{32}$.

\section{HaCiA LA AGRAVANTE DE 1848}

Tras la derogación del código liberal ante la irrupción de los Cien Mil Hijos de San Luis, a poco de reintegrado Fernando VII a su absolutista trono, sendos reglamentos de policía, para Madrid y para las provincias, regulan, en 1824, los cuidados concernientes al uso de armas: licencias y tasas, conculcaciones (se equiparan uso y posesión) y penas (multa y hasta un mes de internamiento en prisión que el legislador liberal de la mitad del siglo seguirá reputando demasiado severo y nada proporcionado ${ }^{33}$ ). Y, casi acto seguido - porque el tema inquietaba los ánimos-, aparte de tales disposiciones genéricas con atención singular a este ramo, ya durante la enfermedad del monarca se reitera alguna vez la orden restrictiva, la

\footnotetext{
${ }^{26}$ Diario de Cortes, II, no 97, ses. 31-XII-1821, p. 1560.

${ }^{27}$ Código de 1822, art. 106.6a. Véase SAINZ GuerRA, Juan, La evolución del derecho penal en España (Jaén, Universidad de Jaén, 2004), p. 172.

${ }^{28}$ Diario de Cortes, III, no 117, ses. 20-I-1822, p. 1919.

${ }^{29}$ Montanos FerRÍN, Emma, La inexistencia de circunstancias agravantes en el derecho histórico, en Montanos Ferrín, Emma, y SÁnchez-Arcilla, José, Estudios de historia del derecho criminal (Madrid, Dykinson, 1990), pp. 128-130.

${ }^{30}$ Diario de Cortes, II, no 60, ses. 23-XI-1821, p. 924. Váyase a AnTón OnECA, José, Historia del Código Penal de 1822, en Anuario de Derecho Penal y Ciencias Penales, (1965), p. 270.

${ }^{31} \mathrm{BEXON}$, Scipion, Application de la théorie de la législation pénale, ou Code de la Sureté publique et particulière (Paris, Courcier, 1807), 1. III, t. 1º, arts. 15 a 27 (pp. 6-9), con t. $2^{\circ}$, art. 143 (p. 31); y l. IV, t. $1^{\circ}$, arts. 8 a 13 (pp. 6-9).

${ }^{32}$ BeXon, Scipion, Application..., 1. V, t. $3^{\circ}$, arts. 46 a 50 (p. 57).

${ }^{33}$ Reglamento de policía de Madrid, de 20 de febrero de 1824, en Reglamentos para la Policía especial de la Corte, y para la de las Provincias del Reyno (Madrid, Imprenta Real, 1824), arts. 115 a 124, 150 a 155; Reglamento de policía para las Provincias, de 20 de febrero de 1824, ibíd., pp. 24-40, arts. 101 a 104, 113. Véase ArRAZOlA, Lorenzo, et al., cit. (n. 3), III, p. 594.
} 
más directa en $1833^{34}$, con ahincada frecuencia luego, en los primeros compases, ya isabelinos, de la Década moderada, fundamentalmente en sendas reales órdenes de 1844 y $1846^{35}$, justo antes de la granazón definitiva del proceso codificador penal en España, lo que demuestra como nada la insuficiencia, siglo XIX adelante, de aquella inveterada legislación que se sostenía en las recopilaciones.

Así, Escriche en 1838, a la vista de los permisivos hábitos, entendía que "ya que asi se mira con tanta connivencia este abuso, mejor seria tal vez alzar absolutamente la prohibición", mas sin tenerlas todas consigo, pues no logra desechar del todo dudas (o bien habla la ironía por su boca), que "[...] siempre parece mas útil proscribir con rigor estas armas que tolerarlas, porque la libertad de su uso produciria mas mal que bien [...]", de donde concluye que "si es que la consideracion de la gravedad de las penas influye en la connivencia que se observa, seria quizá un castigo suficiente y mas eficaz la confiscacion de las armas y una multa proporcionada á las circunstancias, ó bien en lugar de multa la detencion en la carcel por mas ó menos tiempo", y no solo esto, sino que, probablemente por reflexión sobre el Código del 22, sugiere una a modo de agravación "en inteligencia de que al que se sirviese de una arma prohibida para cometer un delito, se le deberia imponer otra pena mayor que estas, además de la correspondiente al delito principal'36. Gómez de la Serna y Montalbán siguen dando razón en 1842 de cómo "la ley castiga el uso de armas prohibidas con la pena de seis años de presidio, y su espendicion con la de cuatro por la primera vez, y de seis por la segunda", si bien avisan igualmente de que "esto no está en práctica en todos los tribunales" 37 . En la misma fecha, los reformadores del Febrero aumentado dejan constancia de que "[...] al efecto han acudido algunas corporaciones respetables al Congreso, pidiendo la abolicion de las antiguas leyes", barruntando la posibilidad de que al cabo "[...] se permitiera el uso absoluto de las armas de todas clases, como parece reclaman las ideas reinantes" 38 y hemos leído plantearse a Escriche. Y al año siguiente consigna García Goyena (quien pronto va a estar debatiendo, comisionado, los balbuceos compositivos del venidero código) cuánto "la pena ha parecido demasiado dura, y los tribunales la mitigan en su duración haciéndola además redimible por no reputarse feo este delito. [...] Pero

\footnotetext{
${ }^{34}$ Real orden comunicando al Sr. Secretario del Despacho de Gracia y Justicia para que se observe lo prevenido por las leyes acerca del uso de armas, de 26 de marzo de 1833, en Decretos del Rey Nuestro Señor Don Fernando VII y de la Reina su Augusta Esposa: reales órdenes, resoluciones y reglamentos generales expedidos por las Secretarías del Despacho Universal y Consejo de S. M., 18, pp. 76-78.

${ }^{35}$ Real orden Prohibiendo el uso de amas al que no esté autorizado por las leyes, de 14 de julio de 1844, en Colección de las leyes, decretos y declaraciones de las Cortes, y de los reales decretos, órdenes, resoluciones y reglamentos generales expedidos por los respectivos ministerios, 33 (1844), pp. 32-34; Real órden, mandando que nadie pueda usar armas sin estar autorizado en la forma que se expresa, ibíd., 38 (1846), pp. 76-77. Acúdase a la voz Armas, en Enciclopedia jurídica española (Barcelona, Francisco Seix, 1910), III, pp. 403-405.

${ }^{36}$ EsCRiche, Joaquín, cit. (n. 7), I, p. 348.

${ }^{37}$ Gómez de la Serna, Pedro, y Montalbán, Juan Manuel, Elementos del derecho civil y penal de España, precedidos de una reseña histórica de la legislacion española (Madrid, Vicente Lalama, 1842), III, p. 72.

${ }^{38}$ García Goyena, Florencio, y AguirRe, Joaquín, Febrero, ó Librería de jueces, abogados y escribanos, comprensiva de los Códigos civil, criminal y administrativo, tanto en la parte teórica como en la práctica, con arreglo en tu todo á la legislacion hoy vigente (Madrid, I. Boix, 1842), VII, p. 313.
} 
lo mas chocante é injustificable es que en todos los puntos públicos, prenderías \&oc. se venden las armas prohibidas y estan á la vista de todos como los demás efectos ó artículos de uso y comercio permitido" (coincidirá con esta la denuncia de Pacheco rigiendo ya el corpus objeto de su explanación ${ }^{39}$ ); aparte de este testimonio, entre lo antiguo y el ensayo de 1822, "yo tengo por mas proporcionadas y eficaces estas penas" segundas ${ }^{40}$-despacha Goyena-. Unánime en ello, según vamos a contemplar más abajo, el magistrado y parlamentario Mariano Montañés recalcaba ante las Cortes de 1842 que, pese a esa tolerancia pública y notoria, "[...] de 2000 pasan, si no me equivoco, las causas criminales que anualmente se forman en España sobre armas prohibidas" ${ }^{41}$... Mas a tanto llega la desconexión antijurídica de los hábitos sociales, contra lo prevenido terminantemente en las leyes, que el gobierno se ve en la precisión de vedar la venta de armas prohibidas y mortíferas exigiendo firmeza a las autoridades "[...] interin se propone á las córtes la modificacion de la pena que previenen las leyes vigentes en el particular, como demasiado rigorosa y poco conforme con el estado actual de la civilización”“2. Y, con efecto, se llevó al Congreso el anunciado proyecto regulatorio, al que enseguida atenderemos...

Empero, todavía algunos años antes, tres florescencias conoce la innovadora técnica de legislar mediante códigos en este redivivo ocaso del Antiguo Régimen: allende la metodología, su contenido, anclado aún en las rancias convicciones, trasluce ya, con todo y con ello, no pocas contaminaciones aportadas por el progresismo ilustrado y el espíritu del siglo. En lo atingente al punto ahora discernido, el título específico "De las armas prohibidas" del Proyecto de Código Criminal de 1830 intenta apartarse de la norma penal en blanco que había creado un vacío en 1822 y planteará problemas en 1848, si bien a riesgo de resbalar hacia el reglamentismo: "el que fabricare, introdujere, vendiere, comprare armas cortas blancas o de fuego, a saber dagas, puñales, rejones, navajas de virola o muelle, pistoletes y cachorrillos, pistolas que no sean de arzón, trabucos, carabinas y arcabuces cuyo cañón no llegue a una vara" incurre en pena económica, en tanto se dispone reclusión por un año "a los que usaren de estas armas prohibidas" y otro tipo simplemente multa a "los que lleven consigo palos de remate o cabeza que no lleguen a una vara"; las exclusiones pormenorizan igualmente tipologías: "en estas prohibiciones no se comprenden las espadas o espadines de vestir, ni las espadas que pasen de vara, ni las pistolas de arzón concedidas a los nobles o hijosdalgo, ni los cuchillos de monte o bayonetas cuando se llevan con escopeta, y no pudiéndolos llevar de otra manera"; apura el título un precepto dirigido a los individuos de la fuerza armada que cayeren en estos excesos, de idéntico correctivo, aunque especificando el perdimiento de las $\operatorname{armas}^{43}$. Los comisionados de 1834 dirán de este trabajo preparatorio y sobre este

${ }^{39}$ PaCheco, Joaquín Francisco, cit. (n.1), p. 258.

${ }^{40}$ García Goyena, Florencio, cit. (n. 6), I, pp. 241-242.

${ }^{41}$ Diario del Congreso, II, ses. 87 (12-IV-1842), p. 2370.

${ }^{42}$ Orden Para que se impida la venta de armas prohibidas fabricadas en Albacete, de 9 de marzo de 1842, en Coleccion Legislativa. Parte segunda, 3 (1842), pp. 86-87.

${ }^{43}$ El Proyecto de Código Criminal de 1830 (Murcia, Universidad de Murcia, 1978), arts. 159 a 162 . 
punto "[...] que nada se puede quitar ni añadir", sino que sus cláusulas "llenan sus objetos; y si no hay minuciosidad, se advierte la suficiente reunión de principios y cánones que deben servir de gobierno para todos, sin peligro de confusión ni de extravio en su inteligencia y aplicación" ${ }^{4}$, lo que a fuer de coherentes les impele a seguir las pautas que en él hallan marcadas, así en su globalidad como en este apartado de armas prohibidas, con cuyo nivel de detallismo llegan a conformarse orillando la tenue objeción.

Sainz de Andino, abre su articulado, en garantía del orden público, con un precepto que, como no fuere eco de un debate harto indeciso -y aun así-, ha de juzgarse ocioso y hasta algún tanto absurdo: repitiendo el epígrafe de la sección, "la fabricación, venta, introducción en el Reino y uso de las armas prohibidas es delito", para amagar a continuación sobre la línea del proyecto precedente con lo que anuncia ser un inventario de armas vedadas, solo que al punto se queda en difusa redacción e impenitente recurso a la remisión reglamentaria, de manera que "son armas prohibidas por punto general", primeramente, "los fusiles, escopetas, carabinas, arcabuces, pistolas y toda especie de armas de fuego que no tengan las dimensiones prescritas por las ordenanzas de su respectiva fabricación, o por los reglamentos de policía y orden público"; en segundo lugar, "las espadas, dagas, cuchillos, navajas y toda otra arma blanca que tanto en sus tamaños como en la forma de su construcción, no se hallen conformes a los que se previene en las ordenanzas y reglamentos que son respectivos a su fabricación"; solo en último término se alarga a precisar "los bastones, cañas o palos que contengan en su interior o en sus cabos y remates instrumento punzante o cortante"; más todavía: la recriminación penal se extiende a las armas "[...] que por disposiciones especiales se prohiban a indivíduos o clases determinadas, o que solamente se permitan bajo ciertas formalidades y requisitos", así como a "los individuos que por concesión personal o por razón de su clase estén autorizados para llevar armas que se hallen generalmente prohibidas, [...] siempre que se excedieren [...]" en calidad, tiempo, ocasión o modo ${ }^{45}$. En cuanto a la tipología, reconviene la industria, el contrabando y el comercio con reclusión de uno a dos años, más sanción monetaria; el simple porte de las armas, además de multa menor, con privación de libertad de cuatro meses a un año, pero en grado máximo si amenazare con ellas; el depósito doméstico, con quince días a dos meses de arresto, más multa $^{46}$. Casabó hace notar la reminiscencia de 1822, con las armas prohibidas entre los delitos contra el orden público (aunque tal será su sitio más habitual) ${ }^{47}$, pero también con su bifurcación como circunstancia agravante de otras conductas criminalmente antijurídicas: "en todo delito cometido con uso de armas probibidas se tendrá ésta por circunstancia agravante para graduar la pena corporal del delincuente si fuere ésta indeterminada, y en consideración a ella se le impondrán a lo menos las

${ }^{44}$ Consulta o dictamen de la segunda Junta de 1832 sobre los anteriores proyectos, en LASSO GAITE, Juan Francisco, Crónica de la codificación española. 5: Codificación penal (Madrid, Ministerio de Justicia, 1970), II, apd. IV, p. 373.

${ }^{45}$ El Proyecto de Código Criminal de 1831 de Sainz de Andino (Murcia, Universidad de Murcia, 1978), arts. 430, 431, 440 y 441.

${ }^{46}$ Proyecto de 1831 , arts. 432 a 436.

${ }^{47}$ CaSABÓ Ruiz, José Ramón, Estudio preliminar al Proyecto de 1831 cit. (n. 45), pp. 17-18. 
dos terceras partes del máximo que la ley prefija" ${ }^{48}$. La normativa se completa con la prevención de los casos de legítima defensa, algo que ya sopesaron los codificadores de 1822, aunque con diverso arbitrio: ahora, la pena por el uso se aplica en su mínimo y no se diluye en la exención; también se incluye el mandamiento de confiscación e inutilización de las armas aprehendidas, reflejo asimismo tal vez de otra cautela del código trienal ${ }^{49}$.

Según el anticipo arriba hecho, el Proyecto de 1834 copia casi al pie de la letra su indisimulado modelo de 1830 , con algunas variaciones leves de poca entidad a los efectos del presente estudio, como no sea que el uso de armas queda ahora en un simple llevarlas consigo y que el año de encierro reclusorio merecido por aquel se transforma en año de obras públicas; a los miembros de fuerza armada se les acumula aquí la pérdida del fuero; con todo, lo más llamativo parece la inclusión "De las armas prohibidas" dentro "De los delitos privados", colocadas entre los ataques contra la integridad corporal y las estafas ${ }^{50}$, y no "De los delitos públicos" (contra la socied ad llamados en 1822), categorización de que carecía el texto más antiguo, si bien este no dejaba de ordenar tales contravenciones entre aquellas mismas violencias y las injurias. Andino tampoco se sirve de ella, pero con razonable criterio las alista claramente al lado de las que afectan a intereses generales -el orden público, en concreto-. En la exposición, ya postfernandina, de la propuesta a las Cortes y a la Regente se manifiesta que "el libre uso de armas prohibidas, más bien se ha limitado a ciertas clases consideradas como incapaces de abusar de ellas, que se ha mirado como delito; mas como de no imponer penas hubiera sido impracticable su prohibición, la ley las ha determinado como un preservativo de los crimenes" 51 , lo cual da la impresión de condecir no muy bien con aquella índole privada que desde el punto de vista sistemático se asignara a esta previsión penal.

Sobre el escenario antes dibujado para los años treinta del siglo, recuperemos el intento del aludido Montañés, progresista, quien presenta a principios de marzo de 1842 una proposición de ley derogatoria de la legislación penal en esta materia, aduciendo su inutilidad como obsoleta, por no decir la crueldad y barbarie, frente a lo que "[...] nada podria haber más conveniente para sustituir esa legislacion que las disposiciones penales del Código del año 22”, eso sí: co n alg u nas ligeras modificaciones ${ }^{52}$; en siete artículos aprontaba multa por el triple del valor y prisión de cuatro a doce meses para la fabricación, multa por el valor y prisión de uno a seis meses para el uso, asumía la doble agravante de 1822 por el uso y la ocupación al delincuente o sospechoso y desechaba en la parte penal la normativa previa ${ }^{53}$. La comisión nombrada ad hoc, integrado el promotor en

\footnotetext{
${ }^{48}$ Proyecto de 1831 , art. 437.

${ }^{49}$ Proyecto de 1831, arts. 438 y 439. Cfr. notas 16 y 21.

${ }^{50}$ El Proyecto de Código Criminal de 1834 (Murcia, Universidad de Murcia, 1978), arts.

${ }^{51}$ Exposición de la Junta firmada el 16 de julio de 1834 elevando el proyecto, en LASSO GAITE, Juan Francisco, cit. (n. 44), apd. V, p. 393.

${ }^{52}$ Diario del Congreso, II, ses. 55 (3-III-1842), p. 1413.

${ }^{53}$ Proposicion de ley, del Sr. Montañés, marcando las penas en que se incurre por la fabricacion, venta y uso de armas prohibidas, de 28 de febrero de 1842, en Diario del Congreso, II, ses. 55, apd. $1^{\circ}$, p. 1435 , arts. 1 a 4 y 7.
} 362 a 366. 
su seno ${ }^{54}$, emite el procedente dictamen, con retoque del texto original, primero manteniendo la privación de libertad solo en defecto de la multa, para dejarla a lo último sustitutoria nada más que en caso de impago de la sanción pecuniaria por el uso; pese a que la intención paliativa informa su parecer, que "[...] ve de una necesidad indispensable acudir cuanto más antes á cortar los males que una legislacion absurda e impracticable está causando [...]" ${ }^{55}$, en ambos supuestos acaba por endurecer algo las penas de cárcel pensadas por Montañés.

La discusión en el pleno cuenta con la intervención inicial de Juan Antonio Garnica, adscrito al progresismo templado, que no se muestra partidario de amortiguar castigos, sino de solventar la inobservancia de la ley, porque "[...] es un error creer que la opinion pública está pronunciada contra la pena de seis años de presidio que establece la ley recopilada", antes bien lo está "[...] en contra del poco celo del Gobierno, en contra de la poca vigilancia de las autoridades, en contra de los medios ilusorios" ${ }^{56}$. No tan solo el control y represión, sino que el señalamiento de las armas prohibidas lo deja en manos de los bandos de la autoridad ejecutiva territorial ${ }^{57}$, a lo que el ministro Alonso, aparte de cargar contra la penalidad durísima a par de una generalización del uso de armas incluso entre gente morigerada y obediente, le redarguye que "[...] yo nunca convendré en que á los jefes políticos se les dé esa autorización", pues "[...] sobre todo erigiria á esos agentes en legisladores" ${ }^{58}$. Asimismo, Montañés replica a Garnica que "[...] en mi concepto el uso de armas prohibidas no es un delito; será un exceso [...]"59 que habrá de reprimirse, sí, cuando dé en abuso, abuso en el que no incurre ningún ciudadano por ir con esas armas, sino "[...] solo cuando las use contra alguna persona, cuando amenace con ellas ó cuando las presente en público [...]", con ponderación tal que "[...] no llegará la justicia á hacer un registro escrupuloso de su persona si no descubre las armas en público, ó amenaza con ellas ó las usa contra otro" ${ }^{\circ}$; y vuelve sobre la necesidad de atemperar el correctivo a todo trance, porque el móvil de cierto impelente estriba en su actualización, tanto es así que "[...] la comision se satisface y llena su objeto en el momento en que el Congreso haya admitido el pensamiento de variar la sanción penal: que la pena sea ésta o la otra; que se sujete á leyes dadas, ó á reglamentos de buen gobierno, le es indiferente; no formará empeño en ello: solo desea que se varie la actual, porque no conviene que sea la de seis años de presidio", tan precisada de reemplazo, "[...] de modo que sea practicable” ${ }^{61}$. Conviene Gómez de la Serna, uno de esos legisladores y exégetas así

${ }^{54}$ Diario del Congreso, II, ses. 57 (5-III-1842), pp. 1466, 1490.

55 Diario del Congreso, II, ses. 71 (21-III-1842), p. 1930; Dictámen de la comision sobre fabricacion, venta y uso de armas prohibidas, de 15 de marzo de 1842, ibíd., apd. 1º, pp. 19311932; ibidem, ses. 78 (2-IV-1842), p. 2155; Artículos $1^{\circ}$ y $2^{\circ}$ del proyecto de ley sobre fabricacion, venta y uso de las armas prohibidas nuevamente redactados por la comision, de 2 de abril de 1842, ibíd., p. 2157.

${ }^{56}$ Diario del Congreso, II, ses. 87 (12-IV-1842), p. 2368.

${ }^{57}$ Ibíd., pp. 2369, 2371.

${ }^{58}$ Ibíd., pp. 2369, 2371.

${ }^{59}$ Ibíd., p. 2369.

${ }^{60}$ Ibíd., pp. 2369-2370.

${ }^{61}$ Ibíd., p. 2370. 
enmarcados por Tomás y Valiente ${ }^{62}$, con la percepción de que la conducta en tela de juicio, circunscrita a la mera posesión, "[...] no es un delito [...] sino un exceso que debe ser castigado por las leyes de policía”, de que, bien sopesada, nada más que "[...] es un acto preparatorio para un delito [...]", y, de pasar más allá, cuando sí debe punirse, topamos entonces con la dureza e inejecutabilidad de las penas, afortunadamente "[...] un defecto de nuestra legislacion que está corregido por la práctica racional de todos los tribunales [...]" "63; lo que no ve nada claro es el recurso al corpus de 1822: "aquel Código pudo ponerle porque trababa de circunstancias atenuantes y agravantes; pero [...] en nuestras leyes no se habla de esas circunstancias [...]", aparte de que, cuando ello haya de adoptarse, "yo diría tambien que no solo el uso de armas prohibidas, sino el de las permitidas, es una circunstancia agravante en cualquier delito" "64; y la determinación de tipos de armas no la admite objeto de una ley, sino de un reglamento administrativo. Fundado sobre el anacronismo de perennizar este delito, propugna Felipe Gómez Acebo que "lo más sencillo, en mi concepto, hubiese sido declarar que estaban derogadas todas las leyes de la Novísima Recopilacion sobre [...] armas prohibidas, y nada más que esto", endosando a los reglamentos de policía su tratamiento, bien entendido que, "si las armas se consideran como circunstancias agravantes de los delitos, es otra categoría distinta" ${ }^{35}$, sí propia del Código Penal, posicionamiento que se alzará positivado en triunfo al remate de su ardua gestación; y otro magistrado, Pascual Fernández Baeza, le secunda en que "[...] esa designación debe de ser, no de una ley, sino de un reglamento del Gobierno" "66 acaso anualmente modificable. El zaguero discurso de algún vuelo lo profiere Salustiano Olózaga, una de las notabilidades del progresismo, quien, por un lado, resume las aportaciones previas con congratularse de que "por fortuna no ha resonado ni resonará aqui una sola voz que suponga delito el mero hecho de tener una arma prohibida, si bien el tenerla en ciertas ocasiones cuando se comete un crimen puede probar premeditacion y servir de circunstancias agravantes para la imposicion de la pena del delito que se haya cometido con esa misma arma" ${ }^{67}$, mas, por otro, reclama, como hiciera algún informante del Proyecto de $1821^{68}$, "[...] la absoluta libertad de fabricacion de armas, que en mi concepto debe permitirse en España" ${ }^{\text {, }}$, siquiera por utilitario cálculo económico de fomento de una industria acreditada y exportable.

Tras esta sesión la comisión rehízo el proyecto ${ }^{70}$, que hubo de volver a debatirse, con intervenciones que perseveraron en la idea ya vertida por Garnica, La Serna,

${ }^{62}$ Tomás y Valiente, Francisco, Manual de historia del derecho español (3a ed., Madrid, Tecnos, 1981), pp. 624-627.

${ }^{63}$ Diario del Congreso, II, ses. 87 (12-IV-1842), p. 2372.

${ }^{64}$ Ibíd., p. 2372.

${ }^{65}$ Ibíd., pp. 2375-2376.

${ }^{66}$ Ibíd., pp. 2377-2378.

${ }^{67}$ Ibíd., pp. 2375-2376.

${ }^{68} \mathrm{Cfr}$. nota 17.

${ }^{69}$ Diario del Congreso, II, ses. 87 (12-IV-1842), p. 2379.

${ }^{70}$ Diario del Congreso, II, ses. 92 (18-IV-1842), p. 2523; Dictámen nuevamente redactado por la comision sobre fabricacion, venta y uso de armas prohibidas, de 17 de abril de 1842, ibíd., apd. $4^{\circ}$, p. 2531. 
Olózaga y hasta el ministro Alonso de que esta regulación debía ir en puridad al futuro código ${ }^{71}$ : ahora Faustino Rodríguez porfía en que "[...] en vez de conceder ahora al Gobierno esa autorización sin bases, sin norma, sin nada, y en fin, de una manera tan extraña [...] debia dejarse este asunto [...] para cuando se tratase de los Códigos"72; Montañés le opone al punto "[...] que la comision no da ningun voto para legislar al Gobierno, sino que solo le da lo que debe tener, la facultad de reglamentar lo que deba serlo en esta materia, como en las demás"73. Otro tribuno, Mateo Miguel Ayllón, objetaba incongruencia por fundar la agravante sobre una prohibición emanada de unas leyes que con simultaneidad se arrumban, al margen de que se haga sin dar al juzgador una pauta discriminatoria de casos en que debe operar o no la circunstancia modificativa de la responsabilidad ${ }^{74}$. La refutación de Montañés iba a analizar luego los dos preceptos tildados de contradictorios: "[...] en uno se deja la probibición de uso de algunas armas al Gobierno, y en otro se deroga la parte penal existente" "75 y en cuanto al otro aspecto, "es claro que las circunstancias serán más ó ménos agravantes segun el juicio que forme el juez, porque como no hay en el Código nada dispuesto, no hay más remedio que dejarlo al arbitrio prudencial del juez" 76 . Aprobado por el pleno para su envío a la Cámara Alta, con modificaciones ya tan solo formales, queda el propósito restricto en definitiva a excitar al gobierno para que reglamente el ramo, mas abrogando sin mayor retardo la pretérita legislación, y a conservar entretanto y a la espera del apetecido código la agravante para el uso de cualquier modo y en todo delito ${ }^{77}$. Sin embargo, a la postre, "este proyecto de ley, votado por el Congreso, no llegó á serlo por el Senado, y por tanto nunca pasó á ser ley"78; si bien, bastante de lo departido a la sazón determinará las elecciones tomadas en la ley, ya no parcial, sino codificada, del año 48 .

En pro de limitar arbitrio y discrecionalidad judicial ${ }^{79}$ y dentro de un planteamiento favorable a la ampliación, genérica y patente, de la circunstancialidad agravatoria, hasta con aumento desproporcionado de situaciones susceptibles de incidir, agudizándola, sobre el cálculo de pena concreta ${ }^{80}$, el código de 1848 , con novedad que quiebra la tradición que hasta él llega ${ }^{81}$, va a deshacerse de la figura delictiva de armas prohibidas, comedido ahora a reputar su uso como

${ }^{71}$ Diario del Congreso, II, ses. 87 (12-IV-1842), pp. 2368, 2371, 2373, 2378.

${ }^{72}$ Diario del Congreso, II, ses. 100 (27-IV-1842), p. 2746.

${ }^{73}$ Ibíd., p. 2747.

${ }^{74}$ Ibíd.

${ }^{75}$ Ibíd.

${ }^{76}$ Ibíd., p. 2748.

${ }^{77}$ Ibíd., pp. 2748, 2765; Proyecto de ley, aprobado definitivamente por el Congreso, sobre fabricacion, venta y uso de armas prohibidas, de 27 de abril de 1842, ibíd., apd. 1º, p. 2767.

${ }^{78}$ Arrazola, Lorenzo, et al., cit. (n. 3), III, p. 580.

${ }^{79}$ Masferrer Domingo, Aniceto, Tradición y reformismo, cit. (n. 25), p. 142.

${ }^{80}$ Véase SÁnchez González, Dolores del Mar, Las circunstancias modificativas de la responsabilidad criminal en la Codificación penal española, en MASFERrer, Aniceto (ed.), La codificación penal española. Tradición e influencias extranjeras: su contribución al proceso codificador (parte general) (Cizur Menor, Thomson Reuters/Aranzadi, 2017), pp. 322-323.

${ }^{81}$ Véase en IÑESTA PASTOR, Emilia, El Código Penal español de 1848 (Valencia, Universidad de Alicante/Tirant lo Blanch, 2011), p. 532. 
indiciario de una mayor censura jurídico-punitiva, por eso las reduce al cómputo "De las circunstancias que agravan la responsabilidad criminal" por el delito, una de las cuales consistirá en "[...] ejecutarlo haciendo uso de armas prohibidas por los reglamentos" ${ }^{82}$, que en una primera versión preparatoria, a cargo de Seijas Lozano ${ }^{83}$, había sido "la de perpetrarlo con armas desiguales y ventajosas a las del ofendido" ${ }^{44}$ en todo caso, estaba ahí ya, por supuesto, en su ligamen a un delito que se ej ecu ta o perpetra, el deslinde de 1822 -sostenido por Sainz de Andino unos años después y otros tantos más por la iniciativa de Montañés-, con aquella misma exclusión entonces decidida que remarcan los reformadores del Febrero: que "el simple porte no se halla penado por el Código por considerarse esta penalidad como una atribución de las autoridades administrativas en el día" ${ }^{35}$, asignación también presente en la Enciclopedia Española de Derecho y Administración ${ }^{86}$, incluso -arguye Vicente y Caravantes contra otra creencia o interpretación ${ }^{87}$ - con superior rigor en las multas al infligido a las faltas penales codificadas ${ }^{88}$. Sin embargo, dicha delimitación parece mostrarse ahora menos severa, toda vez que el ir armado, aun concurrente en el acto delictivo, dejaría de obrar con repercusión negativa, según la letra de la ley, cuando no hubieran servido las armas de instrumento, ora para la violencia, ora para la intimidación, en tanto que -hagamos memoria- bajo el código anterior contaba agravatoriamente la aprehensión del arma a la hora de una prisión, arresto o detención, dando lugar el sujeto -Calatrava dixit-a una sospecha añadida sobre su conducta; mas tampoco está clara esta inteligencia ahora: exponente de ello, Gómez de la Serna valora como razonable la agravante no ya tan solo por indiciaria de alevosía, sino además en cuanto síntoma de peligrosidad ${ }^{89}$, y esto lo denota sin

${ }^{82}$ Real decreto, mandando que el Código Penal y la ley provisional que dicta las reglas oportunas para la aplicacion de sus disposiciones, se observen como ley en la Peninsula é Islas adyacentes desde el dia $1^{\circ}$ de Julio del corriente año, de 19 de marzo de 1848, en Coleccion Legislativa de España, 43 (1848), disp. 163, pp. 206-305, art. 10.22a.

${ }^{83}$ Antón Oneca, José, El Código Penal de 1848 y D. Joaquin Francisco Pacheco, en Anuario de Derecho Penal y Ciencias Penales, 18/3 (1965), pp. 482-484, 491.

${ }^{84}$ Véase en IÑESTA PASTOR, Emilia, cit. (n. 81), p. 534.

${ }^{85}$ García Goyena, Florencio, et al., Febrero ó Librería de jueces, abogados y escribanos (Madrid, Gaspar y Roig, 1852), V, p. 88.

${ }^{86}$ Arrazola, Lorenzo, et al., cit. (n. 3), III, pp. 582, 591-592, 599-600.

${ }^{87}$ V. gr., Vizmanos, Tomás María de, y Álvarez Martínez, Cirilo, Comentarios al Código Penal (Madrid, J. González y A. Vicente, 1848), I, pp. 152-153. Intégrese con el art. 493 del Código de 1848.

${ }^{88}$ Vicente y Caravantes, José, Código Penal reformado, comentado novísimamente, precedido de una breve reseña histórica del derecho real de España, y seguido de tablas sinópticas (Madrid, Alejandro Gómez Fuentenebro, 1851), p. 102, con base en el art. 505 del Código Penal de 1850 (reforma del art. 493 del Código de 1848), la Ley Decretando la organización y atribuciones de los ayuntamientos y diputaciones provinciales, de 8 de enero de 1845, en Colección de las leyes, decretos y declaraciones de las Cortes, y de los reales decretos, órdenes, resoluciones y reglamentos generales expedidos por los respectivos ministerios, 34 (1845), pp. 8-32, art. 75; e ibíd., Ley Decretando las atribuciones de los gobiernos políticos, de 2 de abril de 1845, pp. 134-137, art. 5.3º. Véase Arrazola, Lorenzo, et al., cit. (n. 3), III, pp. 591, 597.

${ }^{89}$ Gómez de la Serna, Pedro, y Montalbán, Juan Manuel, Elementos del derecho civil y penal de España, precedidos de una reseña histórica de la legislacion española (Madrid, Compañía de Impresores y Libreros del Reino, 1851), III, p. 64. 
duda la mera portación... Asimismo, se aventura a insinuar Aramburu y Arregui que, llevadas las armas y planteada la pertinencia de escarmiento, "[...] aun esto parece debia limitarse á aquellos que puedan infundir sospecha por su conducta" (pero acaso nunca se hace así...), en una línea restrictiva -aunque reveladora de usos- y opuesta a lo que elucidan ya sin ambages algunos otros expositores, "[...] ya que en un sentido bien que un tanto lato viene á usarlas el que las lleva consigo" "1. En sus Comentarios al Código Penal, Vizmanos y Álvarez Martínez ("abogados é individuos de la comision que lo redactó”) vuelven a insistir en la trascendencia de la mudanza obrada antes de apuntalar entre líneas una persecución al acecho del solo uso: con buen sentido político-criminal-encomian-, importante novedad en nuestro derecho, que deparaba penas muy severas a semejantes comportamientos y ahora deja el arreglo completo de este sector a la autoridad gubernativa mediante los reglamentos de policía; ahora bien, "el uso de armas prohibidas para cometer un delito será siempre un motivo justo de agravación [...]", tanto por alevosía como por la idea de sí mis mo que da el implicado : también ellos terminan pensando a fin de cuentas, como motivo justo, en que las tiene en su poder ${ }^{92}$, no ya en que las use o las saque...

Arrazola, persuadido de que el conocimiento de la retención, el porte, como de menor gravedad, pertenece a instancias gubernativas, por tanto, de que lo agravatorio consiste en la instrumentalización de armas en orden al delito ${ }^{93}$, se dilata, de más a más, a recomendar recargo de punición también para el uso de armas permitidas (ya oímos argumentarlo a La Serna el año 42), en este caso a través de presunción iuris tantum confiada a las luces y criterio del poder ju dicial"4 "pero tal vez se haya creido que hubiera sido algun tanto rigorosa semejante declaración" 95 -titubea, con todo-; y preconiza, además, la necesidad de tipificar delictivamente las actividades de fabricación, introducción fronteriza y comercio, en consideración de su mayor transcendencia ${ }^{96}$.

A través de esa línea que arranca de 1822 y pasa por 1831, lo cierto es que en los iniciales trabajos preparatorios de lo que será el código de 1848, llevados a cabo por la Comisión General de Codificación entre 1844 y 1845, la opción que obtiene respaldo legislativo ya aparece asentadamente incontrovertida para los junteros, quienes hacen de las armas prohibidas una "De las circunstancias que agravan la responsabilidad"97. Introducido el proyecto en el Senado, se hizo hincapié en el desafío aceptado de "[...] suavizar la legislación penal sobre delitos

${ }^{90}$ Aramburu y Arregui, Juan Domingo de, Instituciones de derecho penal español arregladas al Código reformado en 30 de junio de 1850 (Oviedo, Benito González, 1860), p. 43.

${ }^{91}$ S., J., y B., A. de, Código Penal de España (Barcelona, Ramón Martín Indar, 1848), p. 30.

${ }^{92}$ Vizmanos, Tomás María de, y Álvarez Martínez, Cirilo, cit. (n. 87), I, pp. 152-153.

${ }^{93}$ Arrazola, Lorenzo, et al., cit. (n. 3), III, pp. 582, 586.

${ }^{94}$ Ibíd., III, pp. 587-588.

${ }^{95}$ Ibíd., III, p. 591.

${ }^{96}$ Ibíd., III, p. 583.

${ }^{97}$ Actas de la Comisión General de Codificación sobre Código Penal (1844-1845), en LASso GAITE, Juan Francisco, cit. (n. 44), II, apd. VI, a. 8, ses. 19-X-1844, p. 530; a. 57, ses. 9-XII1845 , p. 1036. 
castigados antes con rigor" 98 , uno de los así dirimidos el de armas, según vamos viendo. Va de allí al Congreso, donde se debate con el mayor apresuramiento y en principio únicamente en lo respectivo a su necesidad, eludiendo entrar en el fondo; se deslizan, pese a todo, someras calas en él, como, verbigracia, esta omisión notada por el progresista Pío Laborda: "observo tambien, señores, que nada se habla, al menos expresamente y con especialidad [...] con respecto á las armas prohibidas y su uso, y si bien en un artículo se habla de ellas, es como por incidencia, y yo creo, señores, que la calificacion de esto debia hacerse en el Código, y no por disposiciones transitorias. Es una materia muy digna de atencion y de un arreglo definitivo, porque el Congreso sabe muy bien el estado en que se encuentra esta parte de nuestra legislacion, y por cuántas contradicciones no tienen que pasar los tribunales de justicia al aplicar las leyes que hay en la materia, moderándolas unos y extendiéndolas otros hasta el extremo de la severidad"'.

Con análoga inquietud y redoblados argumentos insistía el diputado Antonio Corzo, fiscal de profesión y pronto uno de los desmenuzadores de la Aplicación práctica del Código penal en cuadros sinópticos (1848) o Código penal reformado (1850): "otro de los delitos que echo de menos en el Código es el uso de armas prohibidas, delito muy frecuente en algunos paises, sobre todo en el Mediodía de España, y castigado severamente hasta ahora. Gracias á esta sancion penal, algo se contenia el uso de armas de cierta especie, que con razon las califica la opinion pública de alevosas. Hé aqui uno de los puntos sobre que convenia haber oido á los tribunales, pues es seguro que alguno ó algunos de ellos hubieran clamado por que no se alzara esa prohibicion. Y no se diga que el acto en sí mismo no es inmoral, que no ofende á la sociedad ni á ninguno de su individuos. Estos principios tienen cierta elasticidad, y la misma comision de Códigos se ha aprovechado de ella. Hay muchos delitos que son en gran parte convencionales, que más bien que delitos son ocasion de ellos, pero ocasion próxima y de gran peligro que el legislador tiene derecho á prohibir.y si no, ¿por qué el tener una casa de préstamo sin ciertas formalidades ha de ser un delito como lo ha calificado la comision? ¿Ofende esto á la sociedad en general? ¿Ofende en particular a ninguno de sus individuos? No, señores; puede ofender, hay riesgo de que ofenda, lo mismo que el uso de ciertas armas" ${ }^{100}$.

Tomando sobre sí la tutela de la postura gubernativa, procuró contrarrestarles otro servidor de la fiscalía, Cándido Nocedal -moderado en política antes de derivar hasta el tradicionalismo-, con recurso a premisas éticas y sin hacer mucho caso en realidad de las razones esgrimidas: "ha echado de ménos tambien el Sr. Corzo el delito de uso de armas prohibidas. Yo, señores, no puedo tomar en este punto la defensa del Código penal, porque no tengo la fortuna de ser uno de sus autores; sin embargo, preguntaré al Sr. Corzo: pues qué ¿es delito el uso de armas prohibidas? ¿En qué regla natural, lógica ni legitima se funda la opinion de S. S. para decir que el uso de armas prohibidas es por sí un delito que se debe castigar más ó menos severamente?

\footnotetext{
${ }^{98}$ Diario de las Sesiones de Cortes. Senado. Legislatura de 1847 á 1848, XX, ses. 32 (16-II1848), p. 507 (ibíd., p. 511).

${ }^{99}$ Diario de las Sesiones de Cortes. Congreso de los Diputados. Legislatura de 1847 á 1848, III, ses. 80 (11-III-1948), p. 1725.

${ }^{100}$ Diario del Congreso, III, ses. 81 (13-III-1948), p. 1755.
} 
¿Hay aqui otra cosa más que un hecho prohibido por la ley, que se llama delito porque la ley lo quiere? [ं] Las armas prohibidas no pueden usarlas los hombres de bien para defenderse del hombre malo que con armas no prohibidas pueda venir á ofenderle? Por estas razones, sin duda, no han tenido como delito el uso de armas prohibidas los autores del Código. Pero dice el Sr. Corzo: 'pero el uso de armas prohibidas puede dar ocasion á hacer el mal'. Pues qué ¿no comprende S. S. que eso cuando más será una circunstancia agravante del delito cometido? Si por el uso de armas puede el hombre causar el mal, entonces castíguese la embriaguez, castíguense todos los actos del hombre que puedan colocarle en disposicion de hacer mal'101.

En las observaciones y consultas que fueron elevadas al gobierno desde distintas instancias judiciales o administrativas una vez aprobado el texto y antes de su vigencia preocupan dos cuestiones: una, la de atinar con un efugio procesal adecuado ante o para el enjuiciamiento al presente sub iudice de vulneraciones a la luz de la legislación añeja que la inédita iba a desactivar, el extremo de las armas prohibidas uno de los que se espigan como ejemplo ${ }^{102}$; otra, la falta de los reglamentos pertinentes para llenar la norma penal en blanco que entraña la nueva regulación ${ }^{103}$. La comisión y el gobierno resolverán la primera indicando que debe decretarse el sobreseimiento de las causas pendientes; en cuanto a la segunda, se optaba por mantener el vigor con carácter reglamentario a dichas leyes de la Recopilación -pero tan solo en orden a la clasificación de las armas, no a la represión de ilicitudes- en tanto no pudiera disponerse de nuevas normas clasificatorias procedentes de la Administración.

Pacheco no le encuentra a este motivo de agravación otra concordancia que esa del Código del Trienio liberal, "[...] en que de cualquier modo se hiciese uso de alguna arma prohibida", circunstancia esta que convivía entonces aún -lo sabemoscon la tipificación delictiva de su fabricación, venta, introducción en España y uso: ahora "el uso de las armas, su posesión, sobre todo, no es ya un delito. La ley no prohibe ninguna. [...] Mas lo que la ley no ha querido hacer por si-y justamente, pues que no podia hacerlo bien-, ha autorizado para que lo hagan a los reglamentos de policía, [...] sólo que esos reglamentos, ni crean verdaderos delitos, ni estatuyen considerables penas" ${ }^{104}$. Si, en la Enciclopedia de Arrazola, el catálogo legal de armas conglobadas no se apreciará viable "[...] porque los inventos varían al infinito", así como los caprichos de la moda ${ }^{105}$, aprovecha Pacheco la ocasión para avisar de cómo "[...] esos reglamentos no están hechos, y es menester formarlos. Lo antiguo no puede absolutamente servir en este particular" ${ }^{106}$, mas el decreto de 22 de septiembre viene a desmentir su vaticinio recurriendo precisamente a aquello que él tenía por no servidero: a la normativa recopilada, ahora con revalorización

${ }^{101}$ Ibíd., p. 1759.

${ }^{102}$ SÁnchez GonZÁlez, María Dolores del Mar, La codificación penal en España: los códigos de 1848 y 1850 (Madrid, Boletín Oficial del Estado/Centro de Estudios Políticos y Constitucionales, 2004), pp. 153, 163, 165, 167, 169, 173, 177-178.

${ }^{103}$ Ibíd., pp. 155, 160, 170, 172, 178-179, 189, 191.

${ }^{104}$ Pacheco, Joaquín Francisco, cit. (n.1), pp. 258-259. Cfr. nota 23.

${ }^{105}$ Arrazola, Lorenzo, et al., cit. (n. 3), III, p. 582.

${ }^{106}$ PaCheCO, Joaquín Francisco, cit. (n.1), p. 259. 
infralegal ${ }^{107}$, de tal suerte que "las leyes que prohibian armas son hoy reglamentos que también las prohiben. Se creyó esto necesario: nosotros más bien diríamos que fue cómodo; así, los reglamentos verdaderos, sabe Dios cuándo se harán”; no obstante y una vez que "tenemos, pues, al menos interinamente, algo que supla a los reglamentos que echábamos de menos [...]”, importa delinear con precisión el carácter que tales leyes seculares cobran al prorrogarse su vigencia: "el único efecto de esta disposición, de estos reglamentos improvisados en globo, será la declaración de circunstancias agravantes [...]" de acuerdo con su relación o descripción de las armas proscritas, mientras que en todo lo demás, en sus conminaciones y escarmientos deben tenerse sus extremos por decaídos, esto es: "[...] como leyes penales están derogadas por el Código", con la lógica inferencia, que no importa remachar, de que "por una ley de la Recopilación, conservada hoy únicamente como reglamento, no se puede sentenciar hoy a nadie a presidio", justamente por su derogación en cuanto ley y luego también "[...] porque los castigos que alli se encuentran consignados no son de los que los reglamentos pueden imponer" ${ }^{108}$; la subsistencia funciona, por otra parte -huelga decirlo, pero Arrazola lo hace-, "[...] salvo en aquellos puntos que hayan caido en desuso por ser inaplicables en nuestra época" 109 a dictado de las modas y el progreso. Además, la remisión se entiende comprensiva de otra pervivencia de lo antiguo -apostilla Vicente y Caravantes-: las ordenanzas que rigen en ciertos pueblos o provincias para concierto de este particular ${ }^{110}$.

\section{LA FALTA DE 1870}

El Código Penal del Sexenio desanda el camino político-criminal recorrido expurgando la circunstancia agravante introducida por su predecesor, para reponer las armas prohibidas en el elenco de infracciones, mas no entre los delitos, sino que inculpa de "Faltas contra el orden público" a "los que usaren armas sin licencia" -con lo cual se eclipsa ya la hasta entonces corriente referencia a a rmas prohibidas-y los reprende con pequeña multa ${ }^{111}$; fuera de ello, el retumbante

\footnotetext{
${ }^{107}$ Real decreto, resolviendo varias dudas que ha ofrecido en su aplicacion el Código Penal, de 22 de septiembre de 1848, en Coleccion Legislativa de España 45 (1848), disp. 588, pp. 111-114, art. 10: "Siempre que el Código penal se refiere á disposiciones de reglamentos, como en la circunstancia 22 del artículo 10, si estos forman el todo ó parte de alguna ley anterior, regirán como tales hasta que se publiquen otros, conforme á lo que se dispone en la nota segunda de la ley 11 , título $2^{\circ}$, libro $3^{\circ}$ de la Novisima Recopilacion", sobre observancia literal, sin excusa por desuso, de las leyes del reino no derogadas... Acúdase, v. gr., al extracto que facilitan GARCía GoYENA, Florencio, et al., cit. (n. 85), V, pp. 88-90; o Vicente y Caravantes, José, cit. (n. 88), pp. 100-101.

${ }^{108}$ PaCheCO, Joaquín Francisco, cit. (n.1), p. 260.

${ }^{109}$ Arrazola, Lorenzo, et al., cit. (n. 3), III, p. 591 (convergentemente, pp. 588-589).

${ }^{110}$ Vicente y Caravantes, José, cit. (n. 88), p. 102. Léase también a Castro y Orozco, José de, y Ortiz de ZúNiga, Manuel, Código Penal explicado, para la comun inteligencia y fácil aplicacion de sus disposiciones (Granada, Manuel Sanz, 1848), I, p. 100, quienes escriben sin conocer aún el real decreto de 22 de septiembre.

${ }^{111}$ Ley, autorizando al Ministro de Gracia y Justicia para plantear como provisional el adjunto proyecto de reforma del Código penal, de 17 de junio de 1870, en Colección Legislativa de España, 103, disp. 370, pp. 905-1032, art. 591.3.
} 
delito de disparo de arma de fuego, creado ex novo, es cosa de distinta índole ${ }^{112}$. Groizard apunta concordancias con los códigos chileno, italiano -que también enlaza la agravación circunstancial genérica- y brasileño, si bien los tres recurren a la privación de libertad en su remedio ${ }^{113}$. En la fugaz discusión parlamentaria sobre el proyecto presentado por el ministro Montero Ríos, fue la voz de Francisco Silvela -el ocurrente motejador de dicho cuerpo legal como Código de verano- la más enérgica siquiera para un apresurado y mínimo examen de su contenido, mas sin rozar el asunto de la prescindencia del elemento agravatorio previsto en $1848^{114}$. Glosando Groizard este descarte, se resuelve a apoyarlo "porque de otro modo lo mismo tendría que apreciarse [...] respecto del que provoca que del que es provocado; lo mismo respecto del que está al acecho [...] que del que hiere [...] en riña [...]; del que acomete, que del que se defiende" y, ello entendido, "es, pues, preferible prescindir de esta circunstancia á tener que apreciarla con alguna frecuencia, agravando la situacion de personas que merecían ser tratadas con menos rigor" 115 . De entrada, se muestra en conformidad con la destipificación de 1848, dado que "[...] en buenos principios no puede erigirse en delito un hecho que no es contrario á la nocion del derecho, hé aqui porque el simple uso de armas permitidas ó prohibidas no debe constituir delito tampoco segun la ley positiva", extravío que, por lo demás, dejaría inermes -nunca mejor dicho- a las personas hon radas frente a unos malvados dispuestos a aprovecharse sin escrúpulos de cualesquiera medios en pro de sus pasiones y codicias...; "pero si no constituye delito, produce una especie de alarma el que toda clase de personas usen armas cualquiera que sea su género", de manera que se hace preciso su control por el poder ejecutivo y, entonces, "el que hace, pues, uso de armas en contravencion á lo que establecen los Reglamentos, comete una falta [...]" cuya consumación acierta de pleno el código en reprobar ${ }^{116}$.

Viada se remonta a los reglamentos de 1824 y a alguna de aquellas reales órdenes de los decimonónicos años cuarenta, todavía con sus privaciones de libertad, aunque cortas ya, y onerosas multas, para encarecer cómo "estas penas que por su excesivo rigor cayeran en desuso, no fueron substituidas por ninguna otra ni en el Código de 1848 ni en el reformado de 1850. Muy oportunamente, pues, ha venido la reforma á reprimir convenientemente como última de las faltas contra el orden público, un hecho en que tanto se interesan el buen concepto administrativo y la seguridad personal"117. En cambio, a Gómez de la Serna y Montalbán, que habían saludado con complacencia la nuda agravante del 48, por ende, les "[...] parece mejor lo que estableció el Código primitivo: eligiendo un medio prudente, no

${ }^{112}$ Código de 1870, art. 423. Contextualícese, v. gr., en JimÉNEZ DE AsúA, Luis, El delito de disparo de arma de fuego, en Revista de Ciencias Juridicas y Sociales, 5 (1919), pp. 200-208; y Antón Oneca, José, El Código Penal de 1870, en Anuario de Derecho Penal y Ciencias Penales, 23 (1970) 2, pp. 248-249.

${ }^{113}$ Groizard y Gómez de la Serna, Alejandro, cit. (n. 5), VIII, pp. 424, 426-428.

${ }^{114}$ Diario de Sesiones de las Cortes Constituyentes. Legislatura de 1869 á 1871, J. A. García, Madrid, 1870, n. ${ }^{\circ} 307$, ses. 15-VI-1870, pp. 8883 y ss.

${ }^{115}$ Groizard y Gómez de la Serna, Alejandro, cit. (n. 5), I, p. 367.

${ }^{116}$ Ibíd., I, p. 366.

${ }^{117}$ Viada y Vilaseca, Salvador, Código Penal reformado de 1870. Concordado y comentado (Barcelona, Luis Tasso, 1874), p. 967. 
dejaba impune el hecho en lo que agravaba el delito [...] y manifestaba la reprobacion que merecia al legislador ese hábito de algunas clases de nuestra sociedad [...], que si desapareciera, disminuiria grandemente el número de homicidios á que dá lugar tan vituperable costumbre"118. En 1923 se reintrodujo el delito, ahora ya de tenencia ilícita de armas, por vía de legislación especial ${ }^{119}$, enseguida ampliado por la adventicia Dictadura ${ }^{120}$ aún bajo el ordenamiento penal presidido por el código que fuera revolucionario antes de consolidarse domesticado por la Restauración.

\section{EPílogo EN EL SIGLO XX}

Tras más de medio siglo de promulgado el previo corpus con su sola falta, el código primorriverista adoptaba una posición de todo punto ecléctica para blandir las tres alternativas de sus antecesores: por una parte, aun eliminando las armas prohibidas como circunstancia de la transgresión considerable a los efectos de agravar su pena, sí las admite en cambio entre las condiciones del infractor (índice del subjetivismo abrazado) capaces de obrar esas mismas consecuencias, de suerte que cuenta como una de "las condiciones personales que agravan la responsabilidad [...] llevar habitualmente armas sin licencia"121, envuelta la cláusula con la vida depravada y el conocido temperamento pendenciero, novedades todas de que blasonaba el codificador al presentar el proyecto en el otoño de 1927 y "[...] que muestran hasta qué punto ha sido acogida la apreciación de la personalidad del delincuente como base de la individualización penal que hoy proclaman las modernas teorías penales" ${ }^{122}$. Además, en consonancia con su espíritu autoritario y filiación defensista, por otro lado, castiga con prisión y multa "el uso o tenencia de armas de fuego sin la debida autorización" 123 , con un carácter de disposición general para los "Delitos contra la vida, la integridad corporal y la salud de las personas"; y todavía, incluso, dentro de las "Faltas contra el orden público" confluye, reprimido pecuniariamente, "[...] el uso ilícito de armas, siempre que el hecho no

${ }^{118}$ Gómez de la Serna, Pedro, y Montalbán, Juan Manuel, Elementos del derecho civil y penal de España, precedidos de una reseña histórica de la legislacion española (Madrid, Librería de Sánchez, 1872), III, p. 76.

${ }^{119}$ Ley relativa a la tenencia de armas cortas de fuego, de 2 de agosto de 1923, en Colección Legislativa de España, 81 (1923), disp. 5, pp. 20-22.

${ }^{120}$ V. gr., Real decreto disponiendo que los delitos de robo a mano armada a personas o establecimientos serán considerados como delitos militares y juzgados en juicio sumarísimo, cualquiera que sea la persona que los ejecute, y estableciendo recompensas para las personas que coadyuven a la persecución de estos delitos, de 13 de abril de 1924, en Colección Legislativa de España, 84 (1924), disp. 210, pp. 661-662, art. 3º. Léase a Jiménez DE AsúA, Luis, Código Penal reformado de 27 de octubre de 1932 y disposiciones penales de la República (Madrid, Reus, 1934), pp. 259-260.

${ }^{121}$ Real decreto-ley aprobando el proyecto de Código Penal, que se inserta; y disponiendo que empiece a regir como ley del Reino el día $1^{\circ}$ de Enero de 1929, de 8 de septiembre de 1928, en Colección Legislativa de España, 111 (1928), disp. 12, pp. 21-303, art. 67.1ª.

${ }^{122}$ Primera parte, no impresa, del apéndice en que se publicó el Proyecto de Código Penal, remitido a la Asamblea por el Sr. Ministro de Gracia y Justicia, en Asamblea Nacional. Diario de Sesiones, 3 (23-XI-1927), apd. $1^{\circ}$-a, p. 8.

${ }^{123}$ Código de 1928, art. 542. 
constituya delito" 124 . Acerca de aquel mismo bien jurídico a favor de la indemnidad física, había anunciado también el hacedor técnico de la ley la incorporación de disposiciones tomadas "[...] del Real decreto de 13 de Abril de 1924, relativo a la tenencia ilícita de armas de fuego, disposición que en opinión de una gran mayoría de Fiscales ha contribuido en modo extraordinario a la disminución de la delincuencia de sangre"125 (y que Antón Oneca juzga entre las leyes del régimen "[...] obedientes a empiricas exigencias defensistas [...] interpretando la defensa social como defensa política o de clase" ${ }^{126}$ ), convencimiento pleno del cual debió de proceder el blindaje esencialmente político del rescatado delito: "[...] la Comisión de la Asamblea pidió se suprimiese la tenencia, dejando sólo como punible el uso, a lo que el Ministro no ha accedido" 127 ; de seguido, añadía el alegato oficial cómo "al mismo deseo de atenuar los delitos ejecutados con estas armas, que tanto incremento llegaron a alcanzar en nuestro país, responde [...]"128 el siguiente artículo del proyecto, no positivado a la postre en la versión accedida a la Gaceta, en el que se pretendía establecer el grado máximo de pena para la ejecución de homicidio, asesinato, parricidio o infanticidio mediante arma de fuego ${ }^{129}$.

El Código de 1932 se desprende de toda referencia a tales atenciones, por cuanto que, "elevado este hecho a la categoría de delito por vigentes disposiciones de la República, no podia ya figurar como falta. Por ello se ha suprimido [...]"130 con relación al texto de 1870 que se está reformando y con alusión, pues, a la ley de enero de 1932 sobre tenencia, prefigurada por un decreto de agosto del año anterior $^{131}$. Como en 1870 , el disparo de arma de fuego dentro de población o en sitio público o frecuentado presenta otra fisonomía que la que venimos contemplando ${ }^{132}$. Antes del alzamiento antirrepublicano, se dictaron, en 1933

${ }^{124}$ Código de 1928, art. 802.

${ }^{125}$ Primera parte, no impresa, cit. (n. 122), p. 24. Consúltese el Real decreto disponiendo que los delitos de robo a mano armada a personas o establecimientos serán considerados como delitos militares y juzgados en juicio sumarisimo, cualquiera que sea la persona que los ejecute, y estableciendo recompensas para las personas que coadyuven a la persecución de estos delitos, de 13 de abril de 1924, en Colección Legislativa de España, 84 (1924), disp. 210, pp. 661-662, especialmente en su art. 3º.

${ }^{126}$ Antón, José, Los antecedentes del nuevo Código Penal (Madrid, Reus, 1929), p. 17.

${ }^{127}$ San Martín Losada, Luis, El Código Penal de 1928: su estudio y comparación con el de 1870 (Madrid, Imprenta Clásica Española, 1928), p. 156.

${ }_{128}$ Primera parte, no impresa, cit. (n. 122), p. 24.

${ }^{129}$ Proyecto de Código Penal, remitido por el señor Ministro de Gracia y Justicia, en Asamblea Nacional. Diario de Sesiones, 3 (23-XI-1927), apd. 1º-b, art. 698.

${ }^{130}$ Ley de 27 de octubre de 1932 promulgando el Código Penal de 1870 reformado según la Ley de Bases de 8 de Septiembre, en Colección Legislativa de España, 131.4 (1932), disp. 1614, p. 608 (exposición de motivos). Atiéndase a JiméneZ de Asúa, Luis, Código, cit. (n. 122), pp. 259-268.

${ }^{131}$ Decreto dictando reglas relativas al uso de armas cortas de fuego, de 19 de agosto de 1931, en Colección Legislativa de España, 125 (1931), disp. 1442, pp. 501-503; Ley relativa a la tenencia de armas de fuego sin la guia o sin la licencia correspondiente, de 9 de enero de 1931, ibíd., 128 (1932), disp. 67, pp. 93-94.

${ }^{132}$ Código de 1932, art. 563. 
("[...] para dotar a la ley de 1932 de la flexibilidad debida"133) y en 1934, otras dos leyes sobre tenencia de armas de fuego ${ }^{134}$.

Con el precedente de algunos artículos de la Ley de Seguridad del Estado, de $1941^{135}$, el Código de 1944 creará una sección "De los delitos contra la seguridad interior del Estado" para ocuparse "De la tenencia y depósito de armas y municiones"136, cuya primera estipulación comienza por punir con prisión menor "la tenencia de armas de fuego fuera del propio domicilio, sin poseer la guía y la licencia oportunas, o en el propio domicilio, sin la guía de pertenencia [...]"137. Su preámbulo justifica la novedad en un designio de "inserción de las disposiciones posteriores a 1870, establecidas o aceptadas por el Nuevo Estado que no alteren la armonía cientifica del Código [...]"138; es decir: llevando al código lo que la República había mantenido como legislación especial. A lo largo de su recorrido positivo, así como en las refundiciones de 1963 y 1973 , se contó para su complemento referencial con los Reglamentos de Armas de 1944 y de $1981^{139}$.

En fin, el presente Código promulgado en 1995 mantiene la materia "De la tenencia, tráfico y depósito de armas, municiones o explosivos" a cobijo "De los delitos contra el orden público" ${ }^{140}$, con un tipo básico que apresta prisión de hasta tres años para "la tenencia de armas probibidas y la de aquellas que sean resultado de la modificación sustancial de las características de fabricación de armas reglamentadas [...]"141, otra norma penal en blanco, en esta oportunidad con una normativa inferior previa y ya dispuesta para la integración en el Reglamento de Armas de $1993^{142}$, aunque abocada al desacierto por la deficiente técnica remisiva que demuestra Belesta Segura ${ }^{143}$; siguen tipos atenuados para la carencia de permiso

${ }^{133}$ Proyecto de ley leido por el Sr. Ministro de Justicia relativo a la tenencia ilícita de armas de fuego, de 31 de enero de 1933, en Diario de Sesiones de las Cortes Constituyentes de la República Española, 287 (1-II-1933), apd. 6º, p. 1.

${ }^{134}$ Ley relativa al uso y tenencia de armas de fuego, de 4 de julio de 1933, en Colección Legislativa de España, 135 (1933), disp. 958, pp. 12-13. Ley relativa a la tenencia de armas de fuego, de 22 de noviembre de 1934, en Colección Legislativa de España, 141 (1934), disp. 442, pp. 612-615.

${ }^{135}$ Ley para la seguridad del Estado, en Boletín Oficial del Estado, 101 (11-IV-1941), pp. 2434-2444, arts. 10 a 13.

${ }^{136}$ Decreto de 23 de diciembre de 1944 por el que se aprueba y promulga el "Código Penal, texto refundido de 1944", según la autorización otorgada por la Ley de 19 de julio de 1944, en Boletin Oficial del Estado, 13 (13-I-1945), pp. 427-472, arts. 254 a 259, más las disposiciones contenidas en los arts. 265 a 268.

${ }^{137}$ Código de 1944, art. 254.

${ }^{138}$ Código de 1944, exposición de motivos, p. 427.

${ }^{139}$ Decreto de 27 de diciembre de 1944 por el que se aprueba el Reglamento de Armas y Explosivos, en Boletín Oficial del Estado, 19 (19-I-1945), pp. 602-633. Real Decreto 2179/1981, de 24 de julio, por el que se aprueba el Reglamento de Armas, ibíd., 230 (25-IX-1981), disp. 21663, pp. 22382-22396.

${ }^{140}$ Ley Orgánica 10/1995, de 23 de noviembre, por la que se aprueba el Código Penal, en Boletin Oficial del Estado, 281 (24-XI-1995), disp. 25444, pp. 33987-34058, arts. 563 a 570.

${ }^{141}$ Código de 1995, art. 563.

${ }^{142}$ Real Decreto 137/1993, de 29 de enero, por el que se aprueba el Reglamento de Armas, en Boletin Oficial del Estado, 55 (5-III--1993), disp. 6202, pp. 7016-7051.

${ }^{143}$ Belesta Segura, Luis, Aproximación al estudio del delito de tenencia de armas prohibidas, en Revista de Derecho y Proceso Penal, 9 (2003), pp. 67-91. 
administrativo y otros más rígidos contra la fabricación y comercio cuya punición ambulatoriamente privativa puede alongarse hasta unos diez años no diré que reminiscentes de los presidios dieciochescos cuya duración desatara antaño toda la polémica.

Con esto queda completo el panorama en su tránsito hacia la actualidad, ya entrado un siglo XXI en que no parece que se esté por volver a desincriminar estas contingencias o a rebajarles correctivos, sino todo lo contrario ante la emergencia de inquietantes amenazas terroristas y la proliferación del crimen organizado. Empero, el objetivo justificante de las páginas que anteceden se contraía a inquirir discernimientos y titubeos del legislador decimonónico. En la esfera legislativa adoptada como campo de trabajo, el bien jurídico protegido viene sugerido con bastante aproximación, al menos intencional (y contando con zigzagueos y contradicciones), por el título legal bajo el que se decide alojar el tipo: omnicomprensivamente, contra la seguridad interior del Estado, la tranquilidad y el orden público en 1822, amén de la genérica previsión agravatoria por circunstancia indicativa de mayor culpa. Tan relacionados de una u otra suerte entre sí, el proyecto de 1830 no se significa por un excesivo prurito clasificatorio, mas abre un título "De las armas prohibidas" exclusivo y aparte de otros contra la seguridad del Estado y -la más usual cobertura- contra el orden público, que es el bien en que se fija o centra el de 1831, pero el de 1834 sorprendentemente dispone estos temas entre los delitos privados contra la integridad corporal y otros contra el patrimonio, en contacto espiritual con la idea de agravante que termina por preponderar, enfatizando una reprochabilidad indiciaria de alevosía, en 1848. Ya terreno de las faltas, el código de 1870 tiende a proteger el orden público. El de 1928, aparte de la circunstancialidad que determina agravación, agavilla, otra vez frente al delito, la salvaguarda de la vida, la integridad corporal y -ahora, para las faltas- el orden público. En 1944 se vuelve a la seguridad interior del Estado del protocódigo liberal y hoy, desde 1995, las armas se asignan al entorno del orden público que también comparecía ya en 1822 y que ha sido, en resumidas cuentas, su radicación prevalente.

El profesor Masferrer Domingo nos ha esquematizado en tres direcciones el perfeccionamiento del derecho penal codificado: sistematización, humanización y secularización ${ }^{144}$. Dentro de este contexto, el delito de armas prohibidas, rigurosamente castigado en las recopilaciones de la Edad Moderna, se ve sometido a la hora de dicha codificación sectorial a reconsideración bajo un paradigma, el del humanitarismo ilustrado o, mejor, el de la proporcionalidad, que siempre encubre o entraña además cálculos de eficacia coercitiva tendentes a fiar antes el logro de los fines político-criminales en la indefectibilidad de unas penas moderadamente adecuadas que en su aspereza o magnitud; o sea que no se trata esta vez de un vector puro de lenificación punitiva -nunca, de seguro-, traspasado de sentimiento humanitario, porque se advierte motriz ante todo la eficiencia represora por mor de la ecuación de Beccaria: el éxito de las penas depende en general, no

${ }^{144}$ Masferrer Domingo, Aniceto, Tradición y reformismo, cit. (n. 25), p. 71; ÉL Mismo, Tradición e influencias extranjeras en la codificación penal española, en MASFERRER DOMINGO, Aniceto (ed.), La codificación, cit. (n. 80), p. 32. 
de su crudeza, no de su atrocidad, sino de su certidumbre o infalibilidad y de su prontitud ${ }^{145}$; ni hay cumplida identidad entre la cuestión de las armas y la tan fragorosa de los hurtos, particularmente los verificados en la corte y sitios reales a partir de la pragmática de Felipe V en 1734 (que Fernando VII querría restaurar a la altura ¡de 1831!), en la cual, si el replanteamiento estratégico del control punitivo en absoluto queda eclipsado, sí que la inconveniencia y la insostenibilidad de la respuesta legal heredada (jla pena capital!) se exhiben con muchísima mayor ostensión ${ }^{146}$; como sucede también en punto, qué duda cabe, al trabajoso proceso de economización del recurso a ese último suplicio ${ }^{147}$. A lo largo del siglo XIX el legislador va a debatirse entre el mantenimiento de la categoría delictiva atenta a las armas, por descontado que con penalidad ya minorada, su degradación a rango de falta o su conversión en circunstancia agravante de la responsabilidad criminal, hasta que la siguiente centuria -al impulso doctrinal del defensismo o del fenómeno de administrativización del derecho penal hacia su hipertrofiarecupere definitivamente el delito de tenencia ilícita de armas, bien dentro de los sucesivos códigos, bien como legislación de carácter especial. Para un mundo que turbias sinarquías económicas se disputan poniendo en juego todo tipo de recursos así ideológicos como técnicos, competitivas por el control de las masas y sus integrantes, quizás no pueda ser ya de otra manera: el orden internacional reclama, en orwelliana distopía, cada vez con mayor ahínco el sometimiento de los individuos a su vigilancia y conducción, al tiempo que los Estados -cierto es- se ven precisados a luchar contra enemigos exponencialmente dotados de más enérgicos y asequibles medios, aunque el desenlace dependerá tal vez en buena medida del poderío ostentable ante cada unidad política por una de aquellas oligarquías -de una consistencia nada baladí-: la industria armamentística.

\section{BibLiografíA}

Antón, José, Los antecedentes del nuevo Código Penal (Madrid, Reus, 1929).

Antón Oneca, José, El Código Penal de 1848 y D. Joaquín Francisco Pacheco, en Anuario de Derecho Penal y Ciencias Penales, 18 (1965).

- El Código Penal de 1870, en Anuario de Derecho Penaly Ciencias Penales, 23 (1970).

- Historia del Código Penal de 1822, en Anuario de Derecho Penaly Ciencias Penales, 18 (1965).

Aramburu y Arregui, Juan Domingo de, Instituciones de derecho penal español arregladas al Código reformado en 30 de junio de 1850 (Oviedo, Benito González, 1860).

Arrazola, Lorenzo, et al., Enciclopedia española de derecho y administracion ó Nuevo teatro universal de la legislacion (Madrid, Andrés y Díaz, 1850).

${ }^{145}$ BeCCaria, Cesare de, cit. (n. 10), pp. 60-62, 71-73.

${ }^{146}$ Novísima recopilación, XII, 14, 3 y 5 . Intégrese, v. gr., con SEMPERE Y GUARINOS, Juan, Ensayo de una biblioteca española de los mejores escritores del reynado de Carlos III (Madrid, Imprenta Real, 1785/1789), III, pp. 167-178; CASABÓ RuIZ, José Ramón, cit. (n. 12), pp. 315-321; o Tomás y VALIENTE, Francisco, El derecho penal de la monarquía absoluta (siglos XVI, XVII y XVIII) (Madrid, Tecnos, 1969), pp. 252-259.

${ }^{147}$ Ojéese, v. gr., RuIz FunEs, Mariano, Progresión histórica de la pena de muerte en España (Madrid, Editorial Revista de Derecho Privado, 1934), pp. 44 y ss. 
Asamblea Nacional. Diario de Sesiones.

Beccaria, Cesare de, De los delitos y de las penas (1764, trad. cast., Madrid, Alianza Editorial, 1968).

Belesta Segura, Luis, Aproximación al estudio del delito de tenencia de armas prohibidas, en Revista de Derecho y Proceso Penal, 9 (2003).

Bentham, Jeremías, Tratados de legislación civily penal (1821/1822, trad. cast., Madrid, Editora Nacional, 1981).

Bexon, Scipion, Application de la théorie de la législation pénale, ou code de la sureté publique et particulière (Paris, Courcier, 1807).

Boletin Oficial del Estado.

CASABÓ RUIZ, José Ramón, Los orígenes de la codificación penal en España: el plan de Código Criminal de 1787, en Anuario de Derecho Penaly Ciencias Penales, 22 (1969).

Castro y Orozco, José de, y Ortiz de Zúñiga, Manuel, Código Penal explicado, para la comun inteligencia y fácil aplicacion de sus disposiciones (Granada, Manuel Sanz, 1848).

Código Penal francés, traducido al castellano por orden de S. M. el emperador Maximiliano I (1810, trad. cast., México, A. Boix, 1866).

Coleccion de los Decretos y Órdenes Generales Expedidos por las Córtes.

Coleccion Legislativa. Parte segunda.

Colección Legislativa de España.

Decretos del Rey Nuestro Señor Don Fernando VII y de la Reina su Augusta Esposa: reales órdenes, resoluciones y reglamentos generales expedidos por las Secretarías del Despacho Universal y Consejo de S. M.

Diario de las Sesiones de Cortes. Congreso de los Diputados. Legislatura de 1841 á 1842.

- Legislatura de 1847 á 1848.

Diario de Sesiones de las Cortes Constituyentes. Legislatura de 1869 á 1871.

Diario de Sesiones de las Cortes Constituyentes de la República Española.

Diario de las Sesiones de Cortes. Legislatura Extraordinaria. 1821 á 1822.

Diario de las Sesiones de Cortes. Senado. Legislatura de 1847 á 1848.

Enciclopedia jurídica española (Barcelona, Francisco Seix, 1910).

ESCRICHE, Joaquín, Diccionario razonado de legislacion y jurisprudencia (Madrid, Colegio Nacional de Sordo-mudos y Ciegos, 1838/1845).

Filangieri, Cayetano, Ciencia de la legislacion (1780, trad. cast., Madrid, Fermín Villalpando, 1821/1822).

García Goyena, Florencio, Código Criminal español segun las leyes y práctica vigentes comentado y comparado con el Penal de 1822, el francés y el inglés (Madrid, Viuda de Calleja é Hijos, 1843).

García Goyena, Florencio, y Aguirre, Joaquín, Febrero, ó Librería de jueces, abogados y escribanos, comprensiva de los Códigos civil, criminal y administrativo, tanto en la parte teórica como en la práctica, con arreglo en tu todo á la legislacion hoy vigente (Madrid, I. Boix, 1842).

García Goyena, Florencio, et al., Febrero ó Librería de jueces, abogados y escribanos (Madrid, Gaspar y Roig, 1852).

Gómez de la Serna, Pedro, y Montalbán, Juan Manuel, Elementos del derecho civily penal de España, precedidos de una reseña histórica de la legislacion española (Madrid, Vicente Lalama, 1842).

- Elementos del derecho civil y penal de España, precedidos de una reseña histórica de la legislacion española (Madrid, Compañía de Impresores y Libreros del Reino, 1851). 
- Elementos del derecho civil y penal de España, precedidos de una reseña histórica de la legislacion española (Madrid, Librería de Sánchez, 1872).

Groizard y Gómez de la Serna, Alejandro, El Código Penal de 1870 concordado y comentado (Burgos/Salamanca, Timoteo Arnáiz/Esteban Hermanos, 1870/1899).

Iñesta Pastor, Emilia, El Código Penal español de 1848 (Valencia, Universidad de Alicante/Tirant lo Blanch, 2011).

JiméNEZ De AsúA, Luis, Código Penal reformado de 27 de octubre de 1932 y disposiciones penales de la República (Madrid, Reus, 1934).

- El delito de disparo de arma de fuego, en Revista de Ciencias Jurídicas y Sociales, 5 (1919).

Lasso Gaite, Juan Francisco, Crónica de la codificación española. 5. Codificación penal (Madrid, Ministerio de Justicia, 1970).

MASFERRER, Aniceto (ed.), La codificación penal española. Tradición e influencias extranjeras: su contribución al proceso codificador (parte general) (Cizur Menor, Thomson Reuters/Aranzadi, 2017).

MASFerrer Domingo, Aniceto, Tradición y reformismo en la codificación penal española: hacia el ocaso de un mito. Materiales, apuntes y reflexiones para un nuevo enfoque metodológico e historiográfico del movimiento penal europeo (Jaén, Universidad de Jaén, 2003).

Montanos Ferrín, Emma, y Sánchez-Arcilla, José, Estudios de historia del derecho criminal (Madrid, Dykinson, 1990).

PACHECO, Joaquín Francisco, El Código Penal concordado y comentado (1848, reimpr., Madrid, Edisofer, 2000).

Pino AbaD, Miguel, La represión de la tenencia y uso de armas prohibidas en Castilla previa a la codificación penal, en Cuadernos de Historia del Derecho, 20 (2013).

El Proyecto de Código Criminal de 1830 (Murcia, Universidad de Murcia, 1978).

El Proyecto de Código Criminal de 1831 de Sainz de Andino (Murcia, Universidad de Murcia, 1978).

El Proyecto de Código Criminal de 1834 (Murcia, Universidad de Murcia, 1978).

Reglamentos para la policía especial de la Corte, y para la de las provincias del reyno (Madrid, Imprenta Real, 1824).

Ruiz Funes, Mariano, Progresión histórica de la pena de muerte en España (Madrid, Editorial Revista de Derecho Privado, 1934).

S., J., y B., A. de, Código Penal de España (Barcelona, Ramón Martín Indar, 1848).

SaINZ Guerra, Juan, La evolución del derecho penal en España (Jaén, Universidad de Jaén, 2004).

San Martín Losada, Luis, El Código Penal de 1928: su estudio y comparación con el de 1870 (Madrid, Imprenta Clásica Española, 1928).

SÁnchez GonZÁlez, María Dolores del Mar, La codificación penal en España: los códigos de 1848 y 1850 (Madrid, BOE /Centro de Estudios Políticos y Constitucionales, 2004).

Sempere y Guarinos, Juan, Ensayo de una biblioteca española de los mejores escritores del reynado de Carlos III (Madrid, Imprenta Real, 1785/1789).

Tomás y VAliente, Francisco, El derecho penal de la monarquía absoluta (siglos XVI, XVII y XVIII) (Madrid, Tecnos, 1969).

- Manual de historia del derecho español (3a ed., Madrid, Tecnos, 1981).

Viada y Vilaseca, Salvador, Código Penal reformado de 1870. Concordado y comentado (Barcelona, Luis Tasso, 1874). 
Vicente y Caravantes, José, Código Penal reformado, comentado novísimamente, precedido de una breve reseña histórica del derecho real de España, y seguido de tablas sinópticas (Madrid, Alejandro Gómez Fuentenebro, 1851).

Vizmanos, Tomás María de, y Álvarez Martínez, Cirilo, Comentarios al Código Penal (Madrid, J. González y A. Vicente, 1848). 